\title{
Are Addictions Really that Big Problem?
}

\section{Paul T E Cusack}

BScE, DULE 23 Park Ave. Saint John, NB E2J 1R2, Canada.
${ }^{*}$ Corresponding author

Paul T E Cusack, BScE, DULE 23 Park Ave. Saint John, NB E2J 1R2, Canada.

Submitted: 26 Sep 2020; Accepted: 02 0ct 2020; Published: 12 Oct 2020
When invited to submit a paper to this journal on addictions, I thought I would share what I experienced with friends who extensively used alcohol and drugs recreationally.

I grew up in the 1970's in drug infested schools. No one in authority seemed to care. Nothing was done about it. There are four individuals I would like to mention: We will say Jack; Scott; Stephen, Mike, and Mark.

First was Jack who was a weekend alcoholic. Every Friday and Saturday night it was time for a case of beer, taxis to the pubs, and a recovery Sunday morning. He enjoyed his beer. He went on to marry and work steadily as a professionally. The weekend alcoholism did not seem to hurt him a bit.

Second, we consider Scott. Scott was a good friend who started smoking hashish at the age of 13 . He would get high every day. He went on to graduate and rise at the local mill to be union chief. He bought a house in an upper-class suburb, although he had come from the poorest neighbourhood in our fair city. Smoking hashish did not hurt him a bit. He was a graduate of university.

Third was Stephen. He was a drug abuser too in his youth. He like to take LSD. It was something he looked forward to and was his way of keeping interested in things as he was not at all interested in academics. Despite being arrested for drunk driving; he went on to become a fire man (with help from his father). He failed the smoke test -where you must stay in a smoke-filled room and then see how long you can go without requesting oxygen. He got a job driving the truck. They were all smokers.

Fourth, yet another friend, Mike, was a pot smoker while he was at High School and University. Did not hurt him a bit. He went on to become a Law Professor. He married and had children and owns a house. Pot smoking did not hurt him a bit.

Finally, we have Mark. Mark was a daily user of hashish. In Junio High School, he would spend his lunch money on dope. He did poorly in school yet was always pushed ahead. His father was a doctor. His older brother was a drug user, and so was his little brother. His little brother developed Schizophrenia. Whether there is a connection, I do not know. They are also tobacco smokers except Mike. The lung cancer may get them. Of course, my aunt is 90 years old and has smoked all her adult life. The binge drinkers might suffer sclerosis of the liver. They did not have too much trouble with the Law. None went to prison, although one went to jail for littering a beer can in the State of Maine. That same fellow was arrested for drunk driving, but he ended up as a fire truck driver.

Overall, the patter seems to be that drug use even as young as 13 and binge drinking were way for these people to relax and enjoy themselves. I am not sure how to make an argument against drug use and binge drinking expect that some become sick because of it.

All these individuals held down jobs, mated, and had children. So where is the problem with drug abuse and alcohol use? I realize some people lives are destroyed by addictions -themselves and their families. But so are non- drug and alcohol users for a variety of reasons. In my own case, I admit to using hashish and drinking alcohol. I am the one who wound up with schizophrenia, had trouble with the law, and could not hold down a job. Maybe I should have used more drugs and alcohol? I cannot say anything good came from it. If I had had children, I would advise them to stay away from dugs and alcohol. Why? I do not know. Perhaps because its sinful?
Copyright: (C2020 Paul T E Cusack. This is an open-access article distributed under the terms of the Creative Commons Attribution License, which permits unrestricted use, distribution, and reproduction in any medium, provided the original author and source are credited. 